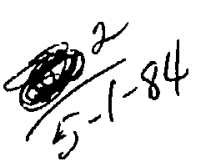

\section{CABLE FABRICATION PROCEDURES FOR THE BPM SYSTEM"}

\author{
W. B. SMITH
}

Stanford Linear Acceierator Center

Stanfard University, Stanford, California y/905

The Uenm Position Monitor (BPM) System is a critical comporont of beam steering and control. It consists of the Beam Position Monitors (in the besmlinc), elnctronic signal processora (fio ated remutely) and the cables that interconncel the two.

Each BPMi prodeces four signals. These four sigasls are tben cumpared clectronically with each oiber. Niterences in amplizude among these signals is converted into information about the position of the beam as it passed that particular BPM.

- In orcer to provide the needed securacy for this system, all four siganls from each BPM musi aive at the prozessing electronics simultaveously. This means the irterconneting eshles must be matehed very precisely. The following procedures, when followed precige'y; will ausure the matehing of BPM cnbles.

TOLERANCE STANDARDS: We use RG223/U cosrial cable for the BPM System. The manufacturer specifies its propagation velocity is $1.54 \mathrm{nS} / \mathrm{ft}$. For the BPM elcetronics to operate accurately, each of the four signals from a single BPM must arrive at the electronies within $0.5 \mathrm{uS}$. And sinee cable runs range from 100 to 300 fect, this requires an accuracy of 3.9 inches of $0.3 \%$ (or beitery!

THEPROBI,EM: Cosiventinal cable mesuremedt, cutting teehniques produce typical accuracies on the ordet of $1 \%$, far too coarse for the BPM System. Heace, the more sophisticated technique that follows.

TIL' TIME DOMUIN REFLECTOMETER (TDH) : This is a marvelously sensitive inateument. When properiy calibrated, it is also extremely accurate. Phase I deseribes ihe proeedure to be followed to calibrate the instrumest. All subsequent work is bighly dopendent upon the are you give this calibration.

- Work supported by the Department of Encrey, contract DF-ACaz-765Foosis, 
Stip 7: Having found the reflected pulse, set the "knce" on the X-Axis 0\% graticule, using a combination of the marker dial and the coarse and fine Horizoutal Positinn adjustnents. When properly done, the "knee" will sit squarcly on the $0 \%$ graticule, the Marker Dial will resd "000" and Switch "B" will be in position " 1 .

Step 8: Set the Maricer Dial to the longth of the longest eable (or to its nanosecond equivalent, if in the time mode). Set Switeb " $B$ " to position "g". Use a jeweler's screwdriver to adjust "VAR" so that the new "knce" falls exactly on tbe $0 \%$ graticyle.

Step 9: The adjustments you made in steps 7 and 8 affect each other. So repent steps 7 and 8 until you can atep from one to the other witnout baving to adjusu citber one.

Step 10: Set Switch "Bn" to position " $3^{n}$ and adjust the Marker Dial for the length of the shorter cable (or its naposecond equivalent if in the time mode). The new "knee" should be very close to the $0 \%$ gtaticule. If rot, combine Steps and 10 and "rock" the calibration to the best compromise you can find. You will find that the accuracy of your eable cutting will have a major impact on the ease with which you are able to accomplish this calibration procedure.

The ealibration proecdure for the TDR is now complete.

i: WARNING * WARNING * WARPING * WARMING "*

IT IS VERY EASY TO BURP OTIER ADJUSTMENTS WHEE MAKJNG ADJUSTMENTS TO THE TDR OR WHILE WORKING WTH TIF CABLES. EVEN THE SLIGHTEST BUNP WII. DESTROY THE ACCURACY. IT IS MPERATNE THAT YOU REPEAT THIS CALIBRATION PRODECIRE ANYTWE YOU SUS PECT THE TDR'S SETTINGS HAVE BEEN DISTURBED IN ANY WAYI

* WARNING $"$ WARNING $\%$ WARNING " WARNING -

THS CALIBRATION PROCEDURE SHAL, FE PERFORMEI TT THE TECN NING OF EACII DAYS WORK AND BEFORE BDGINATNG WORK ON EACH NEW SET OF FOUR BPM CABLXS TO BE TRMMED.

\section{DISCLAIMER}

This report was prepared $z$ an account of wutk spancored by Government. Neither the United Siates fiovernmentorod by an agency of the Ihited Sition

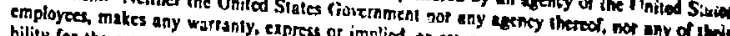

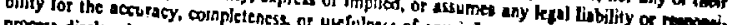

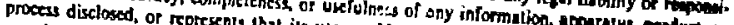
ence hetein to any specific commat its tse would not infringe privately outul product, or

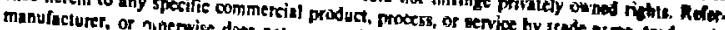

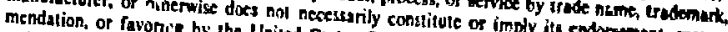

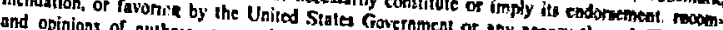
and opinions of authois expresuod herein to not nent of any agency thereot 7 .

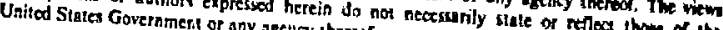




\section{PIIASE II, CABLE TRIMMING}

Step 1: Cut four cables. Make each two to four feet longer than the leagth pre suribed. Terminated one end of each cable with an SMA connector (see nttacted trim code charts for detsils).

Step 2: As in the colibration procedure (Phase I), Switch "B" should bave no cable attached to position " 1 ", the shorter of the two calibration cables ( $\frac{1}{2}$ the length of the loager calibration cable) to position " 3 ". Attach one of the cables to be trimmed to position "4".

Step 3: Confirm TDR ealibration by switebing Switch " $B$ " through the first three positions.

Step 4: Sot the vernier seale to the desired length (length mode) or delay (time mode). Turn Switch "B" through the first three positions.

Step 5: Carefully "prune" the unterminated end of cable \#4 until the reflected pulse's "knce" talls tyithin ONE (1) MINOR DIVISION of the $0 \%$ graticule of the TDR's display.

Step 6: Disconnect the two calibration cables, Connect the three retaining cables of the set of four positions. " 1 ", "2" and "3".

Step ?: Repest Step 5 for cables 1, 2 and 3.

Step 8: Visually compare the four cables with the TDR by switehing "B" through the four positions. NO TWO CABLES SHOULD DIFFER BY MORE THAN 1.5 MINOR DIVISIONS ON THE TDR GRATICULE. ALWAYS TRTM CABLES \#1, \#2 or \#3 as needed to make this match. Cable \#4 is your standard now, and shauld NOT BE TRLMMED.

Step 9: Now that the cables bave been earefully trimmed, terminate the unterminated end with the approprinte connector (SMA or SHV) aceording to the sttached trim code charts.

NoTE: If difficulty is experienced it, the termination procedure and a esble must be retrimmed in order to be properly terminated, repeat Step 8 . If the eable still meetr the standard it Step 8, it is asceptable. If not, then a new cable must be labriested.

\section{PHASE III, ATTENUATION MATCIIING}

Mismatches in attenustion can not be remedied. Thus any cable of a four-esole get that can not meet attenuation tolerances coust be fisearded from the set, ad 2 ocw cable fabritated to take its place. However, a longer cable discard migbt prove astisfactory (onee properly trinned to the new leagth) wh a substitute for a mismalched cable of a dhorter set. Hence it is recommended that the lopgat sets of cabjer be touted for attenuation matching tirst.

ATTENUATION STANIDARD: Each cable of a four-cable set nust be witbin $1 \%$ of esch of the otber three.

Step 1: Set Switeb "B" to position "1". Coanect cable \#1 to haput H. Now connect the free end of cable \#1 to ouput \#1. Observe the TDR display, The retected pulse shoult disappear, confirming proper conpection.

Step 2: Set Switch "B" to positivo "n". Connect cable \$2 to Loput $\$ 2$ and ontput \#2, in much the seme fashion a in Step I. Repeat the procedure for cables \#3 and \#4. Be sure to use the TDR disphy to confrm 1:oper connection in each ease.

Step 3: Set SPDT cosvill Switch "A" 10 "Res" poevitios.

Step 1: Using the oscilloscope, adjut the DELAY GATE GENERATOR (DGG) w that its outpot overlups the leadiag argative pube of the MLSE STRETCIER.

Step 5: Maximize this orerhap by maximiziag the DIGITAL VOLTMITER (DV) resdiog.

Step 6: Step through the four positivas of Switch "U", Lating the DVM values for each poriliod.

Step 7: Compute the devistion between the maxims and misims of the eable ant, Reject any callo which exhibits a Jeviation greater tban $\pm 0.5 \%$ the mean.

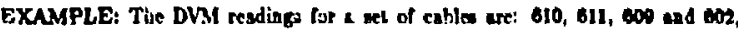
respectively. The mean would be: $(010+911+600+602) / 4$ or $2438 / 4=00$. $\pm 0.5 \%$ of $6003=3.04$. 
Hence allowable attenuation for this set would have to be witbin the span from 604.96 to 611.04. Obviously, cables \#1, \#2, and \#3 meet tbis staudard. But at a value of 602, cable \#4 must be rejected.

Carrying this exampie further, the replacement for cable \#t produccs a DVM seading of 614. A new mean must be calculated (611) and the acceptable $\pm 0.5 \%$ span calculated $( \pm 3.055)$. This new span is 607.045 to 614.055 . Now all four cables are acceptable, although Cablo \#4 just barely makes it.

\section{TRIM CODE CHART}

SMA CONNECTOR:

$$
\begin{aligned}
& A=\frac{14^{*}}{32} \\
& B=\frac{7^{*}}{32} \\
& C=\frac{4^{*}}{32}
\end{aligned}
$$

Use crimp die KTN 2001

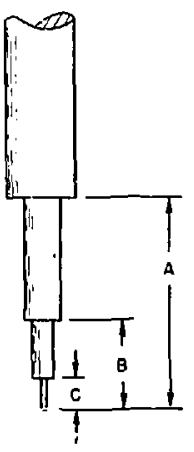

SHV CONNECTOR:

$$
\begin{aligned}
& A=\frac{m}{32} \\
& B=\frac{22}{32} \\
& C=\frac{5}{32}
\end{aligned}
$$

Use condeclor body Kings \# 1705-2 with the slecve !rom a Kings \# 1705-1. Crimp tirst with a KTN 2062 dic and agaip with a KTN 1081 die.

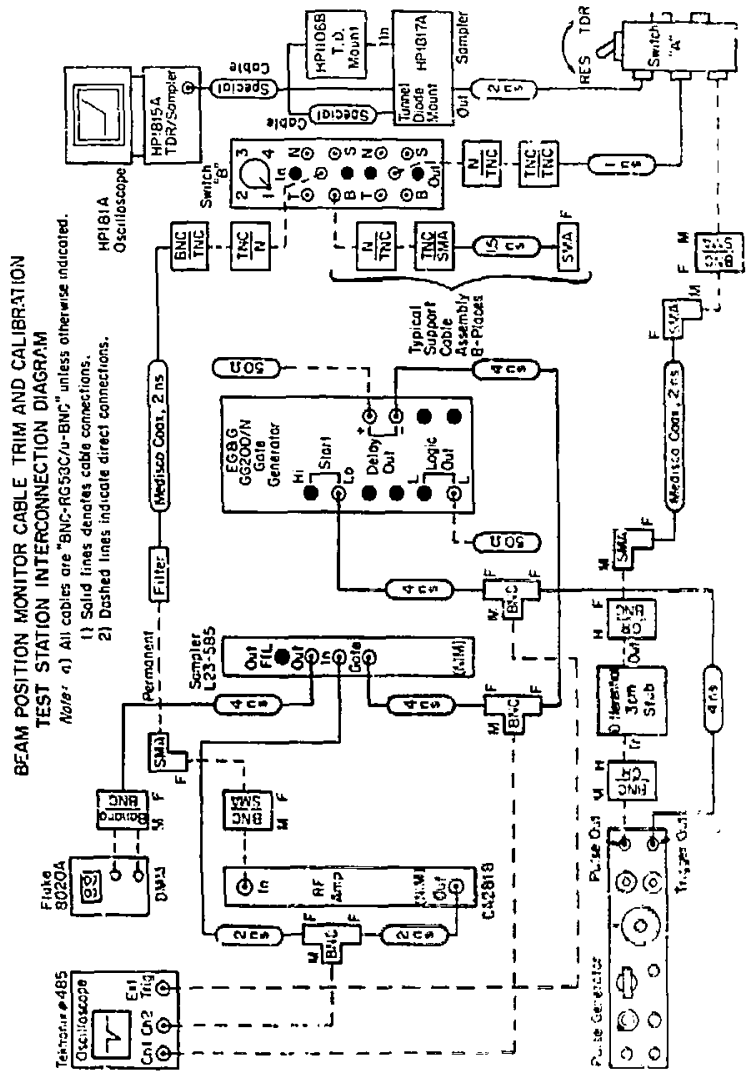

